\title{
Stream Water Quality as Influenced by Beaver within Grazing Systems in Wyoming
}

\author{
QUENTIN D. SKINNER, JOHN E. SPECK, JR., MICHAEL SMITH, AND JOHN C. ADAMS
}

\section{Abstract}

Stream water flowing from watersheds subjected to continuous and deferred rotation grazing by livestock was sampled to enumerate bacteria for detecting differences between grazing treatments and streams. Fecal coliforms, fecal streptococci, total counts at $20^{\circ} \mathrm{C}$, and bacteria capable of fluorescing under long wave radiation were selected as indicators of pollution. The study was conducted two summers, 1979 and 1980 , on mountain rangeland near Laramie, Wyo. Bacteria counts for different indicator groups varied in their ability to detect change between grazing treatments as well as between streams. Fluorescing bacteria and total counts were of little value in explaining nonpoint source pollution whereas fecal coliform and streptococci were. Variation in counts of fecal coliform and streptococci could not be fully accounted for by differences in grazing management but is partially explained by beaver damming of stream flow. Given that beaver impoundment of selected stream reaches is equal, variation in nonpoint pollution may be caused by differences in grazing treatments.

Recently the role of livestock grazing in causing nonpoint pollution to stream flow has received attention (Stephenson and Street 1978, Doran and Linn 1979, Jawson et al. 1982). To help differentiate best management practices for grazing livestock on native rangeland, bacterial indicators of pollution must be determined.

Many researchers have observed elevated fecal coliform and fecal streptococci counts in streams draining grazed rangeland (Morrison and Fair 1966, Kunkle and Meiman 1967, Stevenson and Street 1978, Doran and Linn 1979, Jawson et al. 1982). Declining counts of these bacteria were observed in the streams in pastures after the removal of livestock (Kunkle and Meiman 1967, Skinner et al. 1974b, Milne 1976, Skovlin et al. 1977, Duff 1978, Doran and Linn 1979). Variations in fecal coliforms in streams have been partially explained by rainfall runoff (Doran and Linn 1979, Jawson et al. 1982) deferred grazing management, animal density, access to streams, as well as physical, hydrologic and biological characteristics of drainage basins (Stephenson and Street 1978). In contrast Buckhouse and Gifford (1976) were unable to detect any significant changes in bacterial contamination associated with cattle grazing on watersheds using rainfall simulation to create overland flow. Milne (1976) and Stephenson and Street (1978) have found that livestock being fed on irrigated pastures during winter have a significant effect on bacterial contamination of adjacent streams. Milne (1976) reported, however, that this high contamination was short lived and quickly declined with the cessation of grazing. Bacterial concentrations have been shown by many to vary with stream flow (Morrison and Fair 1966; Kunkle and Meiman 1967; Skinner et al. 1972, 1974b; Stevenson and Street 1978; Jawson 1982).

Indicator bacteria have been found to be more numerous in sediments than overlying water (Hendricks 1971, VanDonsel and

\footnotetext{
Authors are associate professor, former graduate student, and assistant professor Division of Range Management; and associate professor, Division of Microbiology and Veterinary Medicine, College of Agriculture, University of Wyoming, Box 3354, Laramie 8207i

This study was supported by Wyoming Agricultural Experiment Station funds, WYO-153-80. Published as Journal Article 1210 of WAES.
}

Geldrich 1971, Matson et al. 1978). Disruption of sediment has been found to increase fecal coliforms in the overlying water (Grimes 1975). Stephenson and Street (1978) inferred and Stephenson and Rychert (1982) confirmed settling of organisms in sediment could explain higher counts in streams at times when livestock were not present. These studies suggest that it is important to sample both sediment and overlying water to obtain an accurate evaluation of water quality in pastured lands. In addition to sedimentation, increased numbers of indicator bacteria may result from release of cells growing in algae mats (McFeters et al. 1977). They stated that stream aspect, shade, depth, and temperature were important for sustaining algae growth which allowed growth of trapped indictor bacteria.

Johnson et al. (1978) reported that suspended solids in a stream typical of those draining the front range of Colorado were higher in a nongrazed pasture than in an adjoining downstream grazed pasture. Removal of beaver dams in the nongrazed pasture was thought to be the probable cause of the increased suspended solids in the stream. Foote (1937) found little effect of beaver upon the numbers of the coli-aerogens group of bacteria in water above and below beaver ponds. However, he stated that under certain circumstances beaver could excrete large numbers of these organisms.

The purpose of the present study was to monitor change in bacterial counts within streams flowing through 2 different large pasture grazing systems. Beaver activity was prevalent on streams flowing through the study region. Their possible role in explaining differences found in bacteria counts between grazing systems and streams was investigated. Null hypotheses tested include (1) there were no differences in bacterial counts between grazing systems and (2) and there were no differences in bacteria counts between streams studied.

\section{Study Area}

This study was conducted in the Pole Mountain District of the Medicine Bow National Forest, located in the southern extension of the Laramie Mountains of southeastern Wyoming. This area is located between Laramie, Wyo., $18 \mathrm{~km}$ to the west, and Cheyenne, Wyo., $46 \mathrm{~km}$ to the east. Elevation of the study area is between $2,608 \mathrm{~m}$ (west) and $2,250 \mathrm{~m}$ (east). The climate of this region is semiarid. Average annual air temperature is 3.3 to $4.4^{\circ} \mathrm{C}$ and the frost-free period is approximately 60 days. Average precipitation is approximately $430 \mathrm{~mm}$.

The streams in the Pole Mountain District flow in a west to east direction. During the recorded years 1933-1969, peak flow occurred $29 \%$ of the time in April, $44 \%$ in May, and $26 \%$ in June for stream G (Fig. 1) a representative stream of the region (USGS 1964). Low flow occurs in September and remains constant through winter months. Annual runoff for this stream is about 2.96 million $\mathrm{m}^{3}$ (USGS 1964).

Upland soils of the Pole Mountain District are granite derived. Soils along streams are cumulic cryaquolls, Silas Venable Association (Soil Conservation Service, unpublished soil survey, 1981). Vegetation can generally be described as a ponderosa pine (Pinus 
ponderosa savanna (Daubenmire 1943). Cattle are grazed under 2 management systems: continuous season-long and deferred-rotation, from June 1 until October 15. The only continuous system, the Lodgepole allotment, has a gross area of 4,815 ha, 3,481 of which are open and usable for grazing (Johnson 1958). The grazing rate of this allotment is 1.34 ha per animal unit month (AUM).

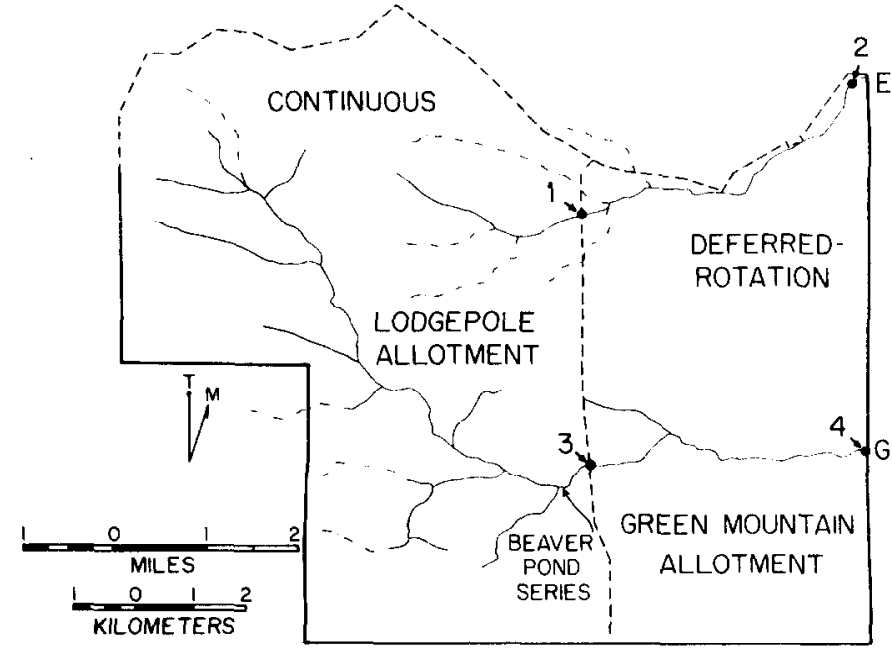

Fig. 1. Water sampling sites in the Lodgepole (continuous) and Green Mountain (deferred-rotation) allotments of the Pole Mountain District.

The deferred-rotation allotments used in this study encompass 3,785 ha, 3,633 of which are open and usable for grazing (Johnson 1958). This four-pasture system completes a rotation in the sequence of use every 4 years. Each pasture is grazed only once during the grazing season, and over 4 years each is grazed at a different time of the grazing season. The stocking rate is 1.58 ha per AUM.

\section{Methods}

Bacteria and sampling sites: fecal coliforms, fecal streptococci, the aerobic plate count on modified Henrici's agar at $20^{\circ} \mathrm{C}$ and flourescent bacteria were monitored. Samples for bacterial analysis were collected every other week from June I to October 15, 1979 (grazing season) and May 1 to June 1, 1980 (spring runoff), June 1 to October 15,1980 (grazing season) from 4 sites located on 2 streams flowing through 2 grazing systcms (Fig. 1). This sampling scheme was initiated to follow the decline of spring snowmelt runoff and base flow during summer and fall months. In addition, 1 sample was collected every other day for 10 days from August 10 to 20,1979 and 1980 (intensive periods). This was done to improve the estimate of bacterial concentrations in streams during low flow conditions.

Basin parameters: total stream, main stream and perennial stream lengths and drainage basin area were calculated for 2 streams. Calculations were made using a map wheel and planimeter from topographic maps (USGS - 15 minute series). Stream flow data from Call (1966) and McDowell (1975) provided yearly flow patterns and relative discharge of respective streams.

Effect of beaver on bacterial numbers: fecal coliforms and fecal streptococci were monitored to evaluate the entrapment of bacteria in beaver ponds. A 3-pond series located on stream $G$, just above site 4 within the continuous grazing system, was selected for collecting water samples just above and bclow each pond. Scdiment cores were collected at 5 points within each pond. Each pond above as well as below was sampled once. Water and sediment samples were compared for difference in the number of organisms above, below, and in ponds.

Number of ponds, impoundment differential, and percent sediment deposition were measured for streams $\mathrm{G}$ and $\mathrm{E}$. A measuring rod was placed at the edge of the dams in the lowest point in the stream channel and vertical distance to a point horizontal to the dam's highest point was recorded. A second measurement in the same manner on the upstream edge of the dam to record distance from top of accumulated sediments to top of dam was made. The upstream measurement was then divided by the downstream measurement. This quotient (impoundment differential) represents the potential of ponds for trapping additional sediment. The quotient, subtracted from 1 and multiplied by 100 , represents sediment accumulation in ponds and is referred to as percent sediment deposited.

Bacterial sampling and processing: water samples were grab samples collected aseptically from streams in sterile 1-liter plastic bottles. Sediment samples were obtained by pushing a sterile kimkap test tube closure $(16 \mathrm{~mm})$ into the sediment. Collections were made at sites in a consistent sequence between 1 and 4 p.m. and were packed in ice and processed within 5 hours of collection.

Total counts of aerobic heterotrophs were made by the spread plate method on a modified Henrici's medium (Stark and McCoy 1938). The plates were incubated for 7 days at $20^{\circ} \mathrm{C}$ to allow for maximum growth to occur (Skinner et al. 1974a). The plates were then placed under long wave ultraviolet light, and colonies capable of fluorescing were recorded (Skinner et al. 1974b, McTernan et al. 1974). Fecal coliforms and fecal streptococci were enumerated by membrane filtration (Standard Methods 1976) using 0.7 micrometer (Millipore-HC) gridded filters. The medium used for fecal coliform was MFC-broth while KF agar was used for fecal streptococci.

Statistical analysis: The analyses of collected data were carried out utilizing an analysis of variance (ANOV) with a completely randomized design. A least squares procedure was applied to data with unequal sample sizes within treatments. Tests were evaluated at the $1 \%, 5 \%$, and $10 \%$ confidence level for significant differences.

\section{Results and Discussion}

\section{Grazing Systems}

Fluorescent bacteria: Counts of these organisms in stream $\mathrm{E}$ and $\mathrm{G}$ ranged from 0.1 to $56 / \mathrm{ml}$ (Table 1). Collins (1963) and Silvey and Roach (1964) found these bacteria in significant numbers in surface waters. Rovira and Sands (1971) found that fluorescent pseudomonads were unevenly distributed in soils, were associated with particulate organic matter, and may be carried by water. Johnstone (1970) implied that these organisms might be useful indicators for monitoring eutrophication between stream reaches. We found no significant differences or distinct trend in counts between grazing treatments. This suggests that fluorescent bacteria were not influenced by different grazing management systems and livestock in this study.

Aerobic Bacteria: Total counts of aerobic bacteria between grazing treatments from stream $\mathrm{E}$ and $\mathrm{G}$ were not significantly different except during spring runoff 1980 in stream $E$ (Table I). There was no difference between total counts for streams except during the 1979 grazing season. Because concentrations of bacteria were generally not different between grazing systems, this bacteriological test does not appear useful for evaluating effect of livestock grazing management practices on water quality.

Fecal Coliforms: During the 1979 grazing season and the period of runoff in the spring of 1980 no significant differences between grazing treatments occurred for streams $\mathrm{E}$ and $\mathrm{G}$. Higher concentrations of these organisms were observed in the deferred rotation treatment during the intensive sampling period in 1980. These high counts may have been caused by recreational activity of humans. This statement is supported by the location of sites E2 and G4 below recreation facilities. During this sampling period in August, recreational activity on the flood plain was observed during sampling. Recreational activity was not observed during the intensive sampling period of 1979. Varness et al. (1978) suggested that changes in fecal coliform counts obtained in a stream system in 
Table I. Bacteria concentrations sampled from streams flowing through continuous and deferred-rotation grazing systems.

\begin{tabular}{|c|c|c|c|c|c|c|}
\hline \multirow{3}{*}{$\begin{array}{l}\text { Bacteria sampled } \\
\text { Sampling period }\end{array}$} & \multirow{2}{*}{\multicolumn{2}{|c|}{$\begin{array}{c}\text { Stream E } \\
\text { Grazing systems }\end{array}$}} & \multirow{2}{*}{\multicolumn{2}{|c|}{$\begin{array}{c}\text { Stream G } \\
\text { Grazing systems }^{a}\end{array}$}} & \multicolumn{2}{|c|}{ Streams $E$ and $G^{a}$} \\
\hline & & & & & \multirow{2}{*}{$\begin{array}{l}\mathrm{E} \\
\text { (Sites 1\&2) }\end{array}$} & \multirow{2}{*}{$\begin{array}{l}\text { G } \\
\text { (Sites 3\&4) }\end{array}$} \\
\hline & $\begin{array}{l}\text { Continuous } \\
\text { (Site 1) }\end{array}$ & $\begin{array}{l}\text { Deferred } \\
\text { (Site 2) }\end{array}$ & $\begin{array}{l}\text { Continuous } \\
\text { (Site 3) }\end{array}$ & $\begin{array}{l}\text { Deferred } \\
\text { (Site 4) }\end{array}$ & & \\
\hline $\begin{array}{l}\text { Fecal coliforms/ } 100 \mathrm{ml} \\
\text { Grazing season } 1979 \\
\text { Intensive period } 1979 \\
\text { Spring runoff } 1980 \\
\text { Grazing season } 1980 \\
\text { Intensive period } 1980\end{array}$ & $\begin{array}{r}140.0 \\
230.0 \\
44.0 \\
250.0 \\
46.0\end{array}$ & $\begin{array}{l}162.0 \\
180.0 \\
21.0 \\
148.0 \\
370.0^{* * *}\end{array}$ & $\begin{array}{r}30.0 \\
141.0 \\
9.0 \\
31.0 \\
27.0\end{array}$ & $\begin{array}{r}37.0 \\
139.0 \\
12.0 \\
65.0 \\
70.0^{*}\end{array}$ & $\begin{array}{l}150.0^{* *} \\
200.0^{*} \\
25.0^{*} \\
200.0^{*} \\
200.0^{*}\end{array}$ & $\begin{array}{r}34.0 \\
140.0 \\
8.0 \\
48.0 \\
48.0\end{array}$ \\
\hline $\begin{array}{l}\text { Fecal streptococci/ } 100 \mathrm{~m} \\
\text { Grazing season } 1979 \\
\text { Intensive period } 1979 \\
\text { Spring runoff } 1980 \\
\text { Grazing season } 1980 \\
\text { Intensive period } 1980\end{array}$ & $\begin{array}{c}140.0^{* * *} \\
20.0 \\
1,100.0^{* *} \\
1,700.0^{* * *} \\
800.0^{* * *}\end{array}$ & $\begin{array}{r}75.0 \\
18.0 \\
400.0 \\
500.0 \\
178.0\end{array}$ & $\begin{array}{r}47.0 \\
67.0 \\
540.0 \\
235.0 \\
130.0\end{array}$ & $\begin{array}{c}87.0 \\
27.0 \\
1,000.0^{* * *} \\
1,180.0^{* *} \\
1,000.0^{* * *}\end{array}$ & $\begin{array}{c}110.0 * * \\
193.0 \\
664.0 \\
1,100.0 \\
500.0\end{array}$ & $\begin{array}{r}67.0 \\
472.0 \\
666.0 \\
700.0 \\
582.0\end{array}$ \\
\hline $\begin{array}{l}\text { Fecal coliform } \\
\text { Fecal streptococci ratio } \\
\text { Grazing season } 1979 \\
\text { Intensive period } 1979 \\
\text { Spring runoff } 1980 \\
\text { Grazing season } 1980 \\
\text { Intensive period } 1980\end{array}$ & $\begin{array}{l}1.0 \\
1.0 \\
0.1 \\
0.4 \\
0.1\end{array}$ & $\begin{array}{l}2.0 \\
1.0 \\
0.1 \\
0.7 \\
2.0\end{array}$ & $\begin{array}{l}0.8 \\
0.3 \\
0.1 \\
0.3 \\
0.2\end{array}$ & $\begin{array}{l}0.5 \\
0.5 \\
0.1 \\
0.1 \\
0.1\end{array}$ & $\begin{array}{l}1.0 \\
1.0 \\
0.04 \\
0.2 \\
0.4\end{array}$ & $\begin{array}{l}0.5 \\
0.3 \\
0.01 \\
0.07 \\
0.08\end{array}$ \\
\hline $\begin{array}{l}\text { Aerobic bacteria/ml } \\
\text { grazing season } 1979 \\
\text { Intensive period } 1979 \\
\text { Spring runoff } 1980 \\
\text { Grazing season } 1980 \\
\text { Intensive period } 1980\end{array}$ & $\begin{array}{l}14,300.0 \\
20,000.0 \\
27,200.0^{* * *} \\
35,600.0 \\
25,200.0\end{array}$ & $\begin{array}{l}11,300.0 \\
15,500.0 \\
14,500.0 \\
11,220.0 \\
21,100.0\end{array}$ & $\begin{array}{l}33,500.0 \\
52,880.0 \\
25,300.0 \\
20,000.0 \\
24,200.0\end{array}$ & $\begin{array}{l}26,000.0 \\
25,700.0 \\
20,000.0 \\
31,700.0 \\
47,000.0\end{array}$ & $\begin{array}{l}12,800.0 \\
18,000.0 \\
24,000.0 \\
23,400.0 \\
23,200.0\end{array}$ & $\begin{array}{l}30,000.0^{* *} \\
39,000.0 \\
26,000.0 \\
25,800.0 \\
35,600.0\end{array}$ \\
\hline $\begin{array}{l}\text { Fluoresent } \\
\text { Bacteria/ml } \\
\text { Grazing season } 1979 \\
\text { Intensive period } 1979 \\
\text { Spring runoff } 1980 \\
\text { Grazing season } 1980 \\
\text { Intensive period } 1980\end{array}$ & $\begin{array}{r}56.0 \\
12.0 \\
30.0 \\
3.0 \\
0.1\end{array}$ & $\begin{array}{r}33.0 \\
10.0 \\
35.0 \\
1.0 \\
0.1\end{array}$ & $\begin{array}{r}22.0 \\
13.0 \\
26.0 \\
0.1 \\
0.1\end{array}$ & $\begin{array}{r}15.0 \\
17.0 \\
29.0 \\
0.1 \\
0.1\end{array}$ & $\begin{array}{l}45.0^{* *} \\
11.0 \\
38.0 \\
0.3 \\
0.1\end{array}$ & $\begin{array}{r}19.0 \\
15.0 \\
34.0 \\
0.1 \\
0.1\end{array}$ \\
\hline
\end{tabular}

"Means identified by ${ }^{* * *}(\alpha=.01),{ }^{* *}(\alpha=.05)$, or ${ }^{*}(\alpha=.10)$ were significantly larger than comparable mean for grazing system or stream.

Washington were related to direct user pressure of streams and adjacent areas.

Fecal Streptococci: Significantly higher concentrations of these organisms were observed in water flowing from the continuous treatment for stream $E$. In contrast stream $G$ had higher concentrations in water flowing from the deferred rotation grazing treatment.

Fecal streptococci may indicate contributions of fecal pollution to streams by warm-blooded animals (Geldrich and Kenner 1969. Geldrich 1970, Geldrich 1976). However, Streptococus bovis, a predominant species in the microflora of cattle feces, implicates livestock as the contaminating source (Doran and Linn 1979). Streptococcus bovis was not enumerated in this study. Contribution of these organisms to streams $E$ and $G$ by livestock is implied by the stream's presence in grazing systems. Doran and Linn (1979) found that fecal coliform/fecal streptococci ratios below 0.05 were indicative of wildlife sources, and ratios above 0.1 were indicative of wildlife sources, and ratios above 0.1 were characteristic of grazing cattle. The range of fecal coliform/fecal streptococci ratios $(0.04$ to 2 ) found in this study indicates that the source of the streptococci in streams $E$ and $G$ was wildlife and livestock.

Because opposite results were obtained between grazing systems for streams $E$ and $G$, we assumed there may differences in streams. These differences may possibly be explained by some drainage basin characteristic.

\section{Streams}

Overall stream $\mathrm{E}$ had higher fecal coliform and fecal streptococci counts during the 2 grazing seasons than did stream G (Table 1). Assuming even distribution of animals per unit stream length or basin area one would expect higher concentrations of bacteria in flow with increased potential for receiving overland runoff to channels. The total length and basin area of stream $E$ was approximately $1 / 2$ that of stream $G$ (Table 2 ) but yet had significantly

Table 2. Drainage basin characteristics for stream $\mathbf{E}$ and $\mathbf{G}$.

\begin{tabular}{|c|c|c|c|c|c|}
\hline Stream & $\begin{array}{c}\text { Total stream } \\
\text { length (km) } \\
\text { (All tributaries) }\end{array}$ & $\begin{array}{c}\text { Main stream } \\
\text { length (km) } \\
\text { (No tributaries) }\end{array}$ & $\begin{array}{c}\text { Perennial stream } \\
\text { length (km) } \\
\text { (No tributaries) }\end{array}$ & $\begin{array}{l}\text { Drainage } \\
\text { Basin (ha) }\end{array}$ & $\begin{array}{c}\text { Representative* } \\
\text { Stream flow }\left(\mathrm{m}^{3} / \mathrm{sec}\right) \\
\text { August } 15 \mathrm{th}\end{array}$ \\
\hline $\begin{array}{l}E \\
G\end{array}$ & $\begin{array}{l}23.2 \\
40.2\end{array}$ & $\begin{array}{r}9.7 \\
16.4\end{array}$ & $\begin{array}{r}9.7 \\
33.6\end{array}$ & $\begin{array}{l}2857 \\
5609\end{array}$ & $\begin{array}{l}0.001 \\
0.021\end{array}$ \\
\hline
\end{tabular}

*From Call 1966 and McDowell 1975 
higher fecal coliform concentrations in the water during the grazing season. Perennial stream length of stream $\mathrm{E}$ is approximately $1 / 3$ that of stream $G$. If animal distribution is concentrated within stream side habitats then one would expect the longer perennial stream length to carry more organisms. This was not the case here.

Differences in amount of flow between streams could be related to higher fecal coliform and streptococci counts in stream E. Stream $\mathrm{G}$ with more flowing water would enhance the chance for dilution of organisms and with increased depth be cooler. Less flow in stream $E$ could be conducive to concentration of nutrients, increased water temperaturd, and growth of algae. Thesc factors could in turn promote additional reproduction of trapped indicator organisms (McFeters et al. 1977). Higher fluorescent counts in 1979 (Table 1) may suggest nutrient increase in stream E (Johnstone 1970). Periodic increase in flow would increase counts downstream through flushing of algae and sediments (McFeters et al. 1977, Stephenson and Rychert 1982).

The higher fecal streptococci counts found in water flowing through the continuous grazing Stream E and deferred rotation grazing system of Stream $\mathrm{G}$ were not fully explained by estimated differences in amount of flow between the 2 streams. The rate of flow through a watershed should be independent of present grazing treatment during any segment of the water year. Beaver activity however in either drainage basin could manipulate flow patterns within any stream reach. The presence of beaver and their activity was not the same on both streams and thus might have affected the observed bacterial numbers within the streams.

\section{Beaver}

In 1980 the beaver ponds were surveyed on stream $E$ and $G$ (Table 3). Stream $E$ had a total of 16 ponds at 4.03 ponds per $\mathrm{km}$ of stream compared to 192 ponds at 30.35 per $\mathrm{km}$ of stream on $\mathrm{G}$. The presence of beaver ponds could cause entrapment of organisms by reducing the velocity of stream flow thereby causing bacteria to settle from stream water to bottom sediment. Stream $G$ had the highest number of beaver ponds and also had significantly lower fecal coliform and streptococci concentrations (Table 1). It appears that entrapment of organisms may be greater on $\mathrm{G}$ resulting in lower fecal bacteria counts in water while total bacterial counts increase with water impoundment. Possibly, growth and multiplication of some members of the bacteria were enhanced by environmental conditions in beaver ponds.

Bacterial counts responded between grazing systems on the same stream in a similar manner. On stream $G$ the continuous system had 41.08 ponds per $\mathrm{km}$ of stream, compared to 12.31 ponds per $\mathrm{km}$ in the deferred system. Numbers of fecal streptococci were higher for the deferred system (Table 1). On stream E there were $1 / 3$ as many beaver ponds on the continuous as on the deferred system. Higher numbers of fecal streptococci were recorded for the continuous treatment (Table 1). Even though the deferred system had more ponds, the number of ponds per $\mathrm{km}$ was similar at 2.94 in the continuous allotment and 4.61 in the deferred allotment. Number of beaver ponds alone may cause differences in bacterial counts in stream flow but does not help explain if one grazing treatment contributes more nonpoint source pollution than does another.

Beaver ponds may be active or abandoned. Newly built and active ponds normally have a greater capacity to store water because less sediment has been trapped. Flood waters behind new dams may dissipate channel flow, thereby reducing stream flow velocity within ponds. Abandoned or older dams are likely to be partially filled with sediment. In this case stream flow would be directed towards a channel within the pond and flow velocity would likely increase, resulting in more scouring of sediments and less deposition of organisms than in newer ponds.

A difference existed in the efficiency of trapping sediment by beaver ponds between grazing systems for stream $\mathrm{G}$ (Table 3 ). The continuous system had a greater average potential for sediment deposition with a differential of 0.71 or $29 \%$ of the pond's capacity was filled with sediment. In the deferred treatment $45 \%$ of the ponds' capacity was filled with sediment. The continuous grazing system with the highest impoundment by beaver dams had the highest potential value for trapping sediment. Bacterial counts were lower with the higher impoundment differential. In stream $E$ the impoundment differential and percent sediment deposited behind beaver dams between grazing treatments was similar between grazing systems (Table 3). Fecal streptococci counts however were not. Counts were significantly higher for this indicator group in the continuous system (Table 1). This seemed to indicate that on stream $E$ with approximately equal water impoundment, bacterial counts were responding to differences in grazing systems. On stream $G$ it appeared that water impoundment may have masked the effect of grazing systems and their contribution to nonpoint source pollution of streams.

Fecal coliforms of water and sediment samples taken from a series of 3 beaver ponds were 13 times more numerous in the sediment samples than they were in water samples (Tablc 4). There

Table 4. Bacterial counts of water and sediment samples taken in a beaver pond series on the Middle Fork of Crow Creek in the Green Mountain (deferred-rotation) allotment in 1980.

\begin{tabular}{|c|c|c|c|c|}
\hline \multirow{2}{*}{$\begin{array}{l}\text { Beaver } \\
\text { Pond }\end{array}$} & \multirow[b]{2}{*}{ Indicator group } & \multicolumn{2}{|c|}{ Water counts ${ }^{\mathrm{a}}$} & \multirow{2}{*}{$\begin{array}{l}\text { Sediment } \\
\text { Counts }\end{array}$} \\
\hline & & Above & Below & \\
\hline \multirow[t]{3}{*}{1} & Fecal coliforms & 32 & 19 & 476 \\
\hline & Fecal streptococci & 245 & 375 & 797 \\
\hline & FC/FS ratios & 0.13 & 0.05 & 0.60 \\
\hline \multirow[t]{3}{*}{2} & Fecal coliforms & 24 & 31 & 235 \\
\hline & Fecal streptococci & 355 & 345 & 456 \\
\hline & FC/FS & 0.07 & 0.09 & 0.52 \\
\hline \multirow[t]{3}{*}{3} & Fecal coliforms & 24 & 20 & 324 \\
\hline & Fecal streptococci & 280 & 400 & 2811 \\
\hline & FC/FS ratios & 0.09 & 0.05 & 0.12 \\
\hline \multirow[t]{3}{*}{$\bar{X}$} & Fecal coliforms & 27 & 23 & 345 \\
\hline & Fecal streptococci & 293 & 373 & 1355 \\
\hline & $\mathrm{FC} / \mathrm{FS}$ ratios & 0.09 & 0.06 & 0.25 \\
\hline
\end{tabular}

Count per $100 \mathrm{ml}$ of water.

${ }^{\mathrm{b}}$ Count per 100 grams of sediment.

Table 3. Beaver impoundment on the main channels of the streams in the continuous and deferred-rotation system-1980.

\begin{tabular}{|c|c|c|c|c|c|}
\hline Streams & Grazing treatments ${ }^{b}$ & Number of ponds & $\begin{array}{l}\text { Number of ponds per } \\
(\mathrm{km}) \text { of stream }\end{array}$ & $\begin{array}{l}\text { Impoundment } \\
\text { differential }\end{array}$ & $\begin{array}{c}\text { Percent sediment } \\
\text { deposited }\end{array}$ \\
\hline $\mathrm{E}$ & $\begin{array}{c}C \\
\text { D-R } \\
\text { C plus D-R }\end{array}$ & $\begin{array}{r}4 \\
12 \\
16\end{array}$ & $\begin{array}{l}2.94 \\
4.61 \\
4.03\end{array}$ & $\begin{array}{c}0.82 \\
0.88 \\
-\end{array}$ & $\begin{array}{l}18 \\
12 \\
-\end{array}$ \\
\hline G & $\begin{array}{c}C \\
D \\
C \text { plus } D-R\end{array}$ & $\begin{array}{r}163 \\
29 \\
192\end{array}$ & $\begin{array}{l}41.08 \\
12.31 \\
30.35\end{array}$ & $\begin{array}{l}0.71 \\
0.55 \\
-\end{array}$ & $\begin{array}{l}29 \\
45 \\
-\end{array}$ \\
\hline
\end{tabular}

\footnotetext{
${ }^{a}$ Average of all ponds in streams or grazing systems

b=Continuous, D-R = Deferred Rotation
} 
were 3 times as many fecal streptococci in the sediment samples.

Water samples collected above and below ponds suggested settling of fecal coliforms occurred (Table 4). These organisms were more numerous in the influents to ponds 1 and 3 than they were in the effluents. In pond 2 fecal streptococci were also less numerous in the effluent. Beaver might be a point source of pollution by contributing bacteria to stream flow as a result of excretion and by stirring sediments. This might explain the higher number of fecal coliforms in the effluent of pond 2 and the fecal streptococci being more numerous in the water below ponds 1 and 3 .

This work extends that of Stephenson and Rychert (1982) and Jawson et al. (1982) to other grazing systems. It follows the findings of Stephenson and Rychert (1982) that water samples alone may be insufficient to assess the impact of grazing upon bacterial water quality and that sediments also need to be sampled. It suggests that beaver ponds may have an influence upon the numbers of bacteria in water. In addition it indicates that bacterial numbers determined for different stream within the same grazing system may not be similar and that results from one stream with a grazing system should not be considered to be representative of other streams flowing through similar systems. Various bacterial populations can be useful as indicators of grazing and other user impacts on rangeland. To be useful significant change must be observed and correlated to a specific user or watershed condition.

\section{Literature Cited}

Buckhouse, John C. and G.F. Gifford. 1976. Water quality implications of cattle grazing on a semiarid watershed in southeastern Utah. J. Range Manage. 29:109-113.

Call, Mayo White. 1966. Beaver pond ecology and beaver-trout relationships in southeastern Wyoming. Univ. of Wyo. and Wyo. Game and Fish Commission, Laramie.

Collins, V.G. 1963. The distribution and existing bacteria in fresh water. Proc. of the Soc. of Water Examination and Treatment. 12:40-73.

Daubenmire, R.F. 1943. Vegetational zonation in the rocky mountains. Bot. Rev. 9:325-393.

Doran, J.W. and D.M. Linn. 1979. Bacteriological quality of runoff water from pastureland. Appl. and Environ. Microbiol. 37:985-99].

Duff, Donald A. 1978. Riparian habitat recovery on big creek, Rich County, Utah-a summary of 8 years of study. Grazing and Riparian/Stream Ecosystems Forum, Denver.

Foote, H.B. 1937. The possible effects of wild animals on bacterial pollution of water. J. Water Pollut. Control. Fed. 29:72-74.

Geldreich, E.E. 1970. Applying bacteriological paramenters to recreational water quality. J. Am. Water Works Ass. 62:113-120.

Geldreich, E.E. 1976. Fecal coliform and fecal streptococcus density relationships in waste discharges and receiving waters. Crit. Rev. Environ. Control. 6:349-369.

Geldreich, E.F. and B.A. Kenner. 1969. Concepts of fecal streptococci in stream pollutions. J. of Water Pollut. Control Fed. 41:336-352.

Grimes, D.J. 1975. Release of sediment-bound fecal coliforms by dredging. Appl. Microbiol. 29:109-111.

Hendricks, C.W. 1971. Increased recovery rate of salmonellae from stream bottom sediment versus surface waters. Appl. Microbiol. 21:279-380.

Jawson, M.D., L.F. Elliott, K.E. Saxton, and D.H. Fortier. 1982. The effect of cattle grazing on indicator bacteria in runoff from a pacific northwest watershed. J. of Environ. Qual. 11:621-627.

Johnson, S.R., H.L. Gary and S.L. Ponce. 1978. Range cattle impacts on stream water quality in Colorado front range. USDA-Forest Service Res. Note. RM-359.
Johnson, W.M. 1958. An evaluation of managing demonstration allotments on Pole Mountain, Medicine Bow National Forest near Laramie, Wyoming. Research Program of the Medicine Bow N.F., Laramie.

Johnstone, D.L. 1970. Bacterial Ecology of the Spokane River. Ph.D. Thesis, Dep. Bac. and Pub. Health, Wash. State Univ., Pullman.

Kunkle, S.H. and J.R. Meiman. 1967. Water quality of mountain watersheds. Hydrology Pap. 21, Colo. State Univ., Fort Collins.

Matson, E.A., S.G. Hornor, and J.D. Buck. 1978. Pollution ind icators and other microorganisms in river sediment. J. Water Poll. Contr. Fed. 50:12-19.

McDowell, Robert A. 1975. A study of the Pole Mountain Fishery: Beaver pond artificial impoundment and stream investigations. Completion Report: D.J. Project F-44-R-01, Fish Div. of the Wyo. Game and Fish Dep., Laramie.

McFeters, G.A., S.A.Stewart, and S.B. Olson. 1977. Growth of heterotrophic bacteria and algal extracellular products in oligotrophic waters. $J$. Appl. and Environ. Microbiol. 35:383-391.

McTernan, W.F., J.C. Adams, and P.A. Rechard. 1973. Comparison of methods for enumerating fluorescent bacteria. Appl. Microbiol. 27:290291.

Milne, C.M. 1976. Effect of a livestock wintering operation on a western mountain stream. Tran. of Amer. Soc. of Agr. Eng. 19:749-752.

Morrison, S.M. and J.F. Fair. 1966. Influence of environment on stream microbial dynamics. Hydrology Pap. 13, Colo. State Univ., Fort Collins.

Rovira, A.D. and D.C. Sands. 1971. Flourescent pseudomonads: A residual component in the soil microflora. J. of App. Bacteriol. 34:253-259.

Silvey, J.K.G. and A.W. Roach. 1964. Investigation of the microbiological cycle in surface waters. J. Am. Water Works. Ass. 56:60-71.

Skinner, Quentin D., John C. Adams, Paul A. Rechard. 1972. Age of changing priorities for land and water. Proceedings Irrigation and Drainage Division Speciality Conference. Amer. Soc. of Civ. Eng., Spokane.

Skinner, Q.D., J.C. Adams, P.A. Rechard and A.A. Beetle. 1974a. Enumeration of selected bacteria populations in high mountain watershed. Can. J. of Microbiol. 20:1487-1492.

Skinner, Q.D., John C. Adams, Paul A. Rechard, and A.A. Beetle. 1974b. Effect of summer use of a mountain watershed on bacterial water quality. J. of Environ. Qual. 3:329-335.

Skovlin, J.M., W.R. Meehan, J.C. Buckhouse, and M. Vavra. A method o study for determining the influence of grazing on riparian and aquatic habitats in the Blue Mountains of eastern Oregon and Washington. In: Symp. Livestock Interactions with Wildlife, Fisheries and Their Environments (Sparks, Nev., May 1977) J. Menke, Ed. USDA For. Serv. Pac. Southwest For. and Range Exp. Sta. Berkeley, Calif.

Standard methods for the examination of water and wastewater. 1976. Am. Pub. Health Ass., Am. Water Works Ass., Water Pollution Control Federation. 14th Ed., Am. Pub. Health Ass., New York.

Stark, W.H., and E. McCoy. 1938. Distribution of bacteria in certain lakes of northern Wisconsin. Zentrallblatt for Bacteriologie Abt. 2:201-209.

Stephenson, G.R. and L.V. Street. 1978. Bacterial variations in streams from a southwest Idaho rangeland watershed. J. of Envrion. Qual. 7:150-157.

Stephenson, G.R. and R.C. Rychert. 1982. Bottom sediment: A reservoir of Escherichia coli in rangeland streams. J. Range Manage. 35:119-123.

U.S.G.S. 1964. Surface water records of Wyoming. U.S. Dep. Interior, Geological Survey

VanDonsal, D.J. and E.E. Geldreich. 1971. Relationships of salmonellae to fecal coliforms in bottom sediments. Water Res. 5:1079.

Varness, K.J., R.E. Pacha, and R.F. Lapen. 1978. Effects of dispersed recreational activities on the microbiological quality of forest surface water. Appl. and Environ. Microbiol. 36:95-104. 